\title{
Blue-Green Infrastructure for Flood and Water Quality Management in Southeast Asia: Evidence and Knowledge Gaps
}

\author{
Perrine Hamel (iD ${ }^{1} \cdot$ Leanne $\operatorname{Tan}^{1}$ \\ Received: 31 October 2020 / Accepted: 23 March 2021 / Published online: 16 April 2021 \\ (C) The Author(s) 2021
}

\begin{abstract}
In Southeast Asia, projections of rapid urban growth coupled with high water-related risks call for large investments in infrastructure-including in blue-green infrastructure (BGI) such as forests, parks, or vegetated engineered systems. However, most of the knowledge on BGI is produced in the global North, overlooking the diversity of urban contexts globally. Here, we review the literature on BGI for flood risk mitigation and water quality improvement in Southeast Asian cities to understand the scope of practical knowledge and identify research needs. We searched for evidence of local types of BGI in peer-reviewed and grey literature and assessed the performance of BGI based on hydrological, societal, and environmental metrics. The body of literature on BGI in Southeast Asia is small and dominated by wealthier countries but we found evidence of uptake among researchers and practitioners in most countries. Bioretention systems, constructed wetlands, and green cover received the most attention in research. Evidence from modelling and laboratory studies confirmed the potential for BGI to address flooding and water quality issues in the region. However, practical knowledge to mainstream the implementation of BGI remains limited, with insufficient primary hydrological data and information on societal and environmental impacts. In addition, the performance of BGI in combination with grey infrastructure, under climate change, or in informal settlements is poorly studied. Future research and practice should focus on producing and sharing empirical data, ultimately increasing the regional knowledge base to promote efficient BGI strategies.
\end{abstract}

Keywords Stormwater management $\cdot$ Natural infrastructure $\cdot$ Nature-based solutions $\cdot$ Flood risk $\cdot$ Ecosystem-based adaptation

\section{Introduction}

Whether it is mitigating flood risk, improving access to clean water or treating urban water effluents, managing water is a top priority for all cities in the world. Naturebased solutions are gaining traction among local governments, multilateral and non-governmental organizations to deliver efficient and sustainable urban water management (Asian Development Bank 2019; Brears 2018; Liu and Jensen 2018; World Wildlife Fund 2016). These

Supplementary information The online version contains supplementary material available at https://doi.org/10.1007/s00267021-01467-w.

Perrine Hamel

perrine.hamel@ntu.edu.sg

1 Asian School of the Environment, Nanyang Technological University, Singapore, Singapore solutions leverage ecosystem services, the benefits provided by nature, to improve water management by restoring a more natural water cycle, for example increasing infiltration, evapotranspiration and pollutant removal (Eckart et al. 2017; Fletcher et al. 2013; Liao et al. 2017). Importantly, nature-based solutions provide a range of additional services such as reducing urban heat island, sequestering carbon and providing aesthetic or recreational value to a city (Depietri and McPhearson 2017; Keeler et al. 2019; Lourdes et al. 2021; Venkataramanan et al. 2019). The multifunctionality of naturebased solutions aligns well with a systemic or 'integrated' approach to water management, one that integrates multiple stakeholders and multiple solutions to increase resilience to water-related hazards (Fletcher et al. 2015; Mitchell 2006; Oral et al. 2020).

Nature-based solutions rely on blue and green infrastructure (BGI), or 'natural infrastructure', the 'interconnected network of natural and semi-natural elements capable of providing multiple functions and ecosystem 
services', ranging from green spaces to riparian and coastal vegetation, street trees and engineered systems such as bioretention or green roofs (Bartesaghi Koc et al. 2017; Benedict and McMahon 2006). The multiple services derived from BGI in a given city depend on a range of social, ecological and technological factors (Keeler et al. 2019). For example, climate and soil characteristics determine how much water is stored in a watershed, making forests more or less effective at storing and slowly releasing water in the dry season (Brauman 2015; Browder et al. 2019). Socio-technical decisions about the water supply system-e.g. reliance on surface versus groundwater-also moderate the value of BGI, by changing the demand of the local groundwater recharge.

Despite the importance of understanding local factors, most of the academic knowledge on BGI was generated in the global North, leaving knowledge gaps about the performance of green infrastructure in other regions (Keeler et al. 2019; Nagendra et al. 2018; Song et al. 2017). Filling these gaps is particularly important in Southeast Asia, where projections of rapid urban growth and important risks of flooding and water pollution make integrated urban water management critical. Southeast Asian countries currently show a 'low' to 'medium low' level of integration, except the Philippines ('medium high') and Singapore ('very high'), highlighting the potential for BGI to be further incorporated in urban water management (UNEP-DHI Centre on Water and Environment 2020).

It is estimated that over 500bn USD are needed to improve water infrastructure in Southeast Asia, with country-level projections varying from 4.6 in Cambodia to 209bn in Indonesia (data excluding Timor Leste, Lao PDR and Brunei) (Global Infrastructure Hub 2020). The share of BGI in these investments will depend on the capacity of public and private sectors to consider and implement nature-based solutions, motivated by regulatory changes (e.g. water quality standards), water security, increased flood risk or ecological considerations (Liao et al. 2017). In practice, it will also require addressing institutional, financial and knowledge barriers to BGI implementation (Sarabi et al. 2020, 2019; Wamsler et al. 2020). The motivation for this paper is to review technical knowledge gaps for two categories of services in Southeast Asia: flood risk mitigation and water quality improvement, focusing on hydrological and engineering knowledge rather than governance or urban planning processes. For eleven Southeast Asian countries, we reviewed the peer-reviewed and grey literature on BGI and extracted information on hydrologic performance (whether BGI is effective at providing waterrelated services) and practical considerations to design and implement BGI in the region. We asked:
- what type of BGI for flood risk and water quality improvement is studied in Southeast Asian cities, and in which countries?

- what is the evidence of hydrologic performance for such BGI?

- what information is available to design and implement such BGI in practice (considering the ecological and socio-technological context of Southeast Asia)?

In the next sections, we describe the characteristics of Southeast Asian countries ('Southeast Asian Ecological and Socio-technical Context') and our methodological framework to review the regional literature ('Methods'). We then organize our findings and discussion according to the three questions above, namely geographic distribution and types of BGI found in the literature, hydrologic performance of BGI and design and implementation factors. By contrasting our findings with the global literature, we conclude with a summary of research gaps and future research directions in the region ('Key Knowledge Gaps').

\section{Southeast Asian Ecological and Socio- technical Context}

Several ecological and environmental features distinguish Southeast Asia from most global North countries. First, the climate-tropical rainforest or tropical monsoon (Beck et al. 2018) - is hot and humid, with high annual precipitation and frequent intense events. This has implications for BGI as more water storage capacity is needed to manage water (Eckart et al. 2017), whether it is for flood control or water quality management. For example, the intensity of a 1-h storm occurring every 2 years in Singapore is equivalent to a storm occurring every 100 years in New York (Cornell University 2015; Public Utilities Board Singapore 2013). It makes the area particularly prone to flood hazards, with Thailand, Cambodia, Vietnam and the Philippines being among the most flood-impacted populations around the world (Hu et al. 2018). Climate change will also exacerbate these trends (e.g. Kefi et al. 2018; Wang et al. 2017). Second, Southeast Asia comprises tropical and subtropical rainforest, dry forest and monsoon forest, species that are understudied in the global literature (Song et al. 2017). Most Southeast Asian trees are evergreen, with only a few deciduous species found in the dry forests (e.g. in Myanmar), resulting in little seasonal variation in ecological functions other than due to climate. Third, Southeast Asian soils generally have high clay contents and medium to low permeability (Acrisol-Alisol types, Chappell et al. 2007). Although this suggests that forests may be less effective at retaining water, the large swaths of forests with highly porous topsoil still provide high drainage rates-making 
them important to protect for water security (Estoque et al. 2019). A final important characteristic of the Southeast Asian landscapes is the presence of large river deltas, including the Mekong, the Irrawaddy and the Chao Phraya deltas, which all comprise large wetland areas. The flat topography of these regions exposes urban and rural settlements to frequent flooding (e.g. Siripong et al. 2000).

From a socio-technological standpoint, Southeast Asian cities range broadly in population density, gross domestic product per capita and governance efficiency (Table S1, Supplementary Information and Lourdes et al. 2021). These characteristics influence the range of BGI that are possible to implement, based on cost and space requirements, among others. Weak urban governance means that official plans are rarely implemented, with market forces rather driving what is built on the ground (Yap 2018). The resulting 'tetris-like' urban sprawl, described by some scholars in China and Southeast Asia (Hedglin 2015; Yap 2018), is at odds with integrated urban water management, which requires finding synergies and complementarities in various components of the water system (Liu and Jensen 2018). In fact, few Southeast Asian cities have an integrated urban water management plan and sanitation remains very low in most countries (Rahmasary et al. 2019). Apart from Singapore and Malaysia, Southeast Asian countries have a low sewerage cover with on average $17.3 \%$ of urban dwellers being connected to a sanitation sewer network (World Health Organisation and UNICEF 2017, see Table S1 for national statistics). Cities rarely have separate stormwater and sanitary sewer systems, with the notable exception of Singapore and, to a lesser extent, cities in Malaysia, Brunei and Vietnam. Most cities include open canals that drain both stormwater and wastewater, often to the nearest river-making water purification an essential service to remove pollution. Subsidence due to groundwater pumping exacerbates flooding issues, as it has been demonstrated in Jakarta, Bangkok or Ho Chi Minh City (Erkens et al. 2015). BGI that increases infiltration may mitigate this issue, while also replenishing groundwater resources for consumption.

Finally, Southeast Asian cities are characterized by high levels of informality. Informal settlements are defined as urban areas developed outside the legal systems and lacking 'risk-reducing infrastructure (paved roads, storm and surface drainage, piped water, etc.) and services relevant to resilience (including healthcare, emergency services and rules of law)' (Satterthwaite et al. 2020). More than 370 million people live in informal settlements in Southeastern and Eastern Asian cities, making up to $50 \%$ of the urban population in some countries (Table S1). These settlements are particularly vulnerable to hydrologic hazards due to the lack of infrastructure and proximity to water bodies. In many cities, informal dwellers both impact and rely on services related to rivers (Vollmer and GrêtRegamey 2013), making them important actors of river management. The uncontrolled growth of informal settlements may exacerbate water management issues by reducing ecosystem services such as water purification and water retention (Harriden 2012). Inexistent or limited waste collection and sanitation services also severely impacts water quality.

\section{Methods}

\section{Review Framework and Search Terms}

Given our focus on hydrological performance and technical design, we use the term BGI throughout the review, which highlights the structural elements of nature-based solutions and the broad focus on urban water management rather than stormwater specifically (cf. discussion of alternative terms by Fletcher et al. 2015; Moosavi et al. 2021). BGI performs a range of ecohydrological functions (infiltration, sedimentation, biodegradation), which provide services (Brauman 2015; Tallis et al. 2012). Using Brauman's framework (2015), we focused on risk mitigation and supporting services. Two are related to flood risk (riverine and stormwater flood mitigation) and rely on the capacity of vegetated systems to intercept, infiltrate and retain rainwater during storms, which reduces runoff volume and delays peak flows. The other two services relate to water quality (stormwater and wastewater management), relying on interception, infiltration and retention, as well as pollutant reduction through sedimentation in water bodies, filtration and biodegradation (Fig. 1).

We searched all scientific databases on the Web of Knowledge platform for peer-reviewed articles published before June 2020 on urban water management in Southeast Asian countries. Our search terms reflected our interest in a broad range of BGI-including site-scale to watershedscale ecosystems - although we excluded marine ecosystems for coastal flood risk mitigation. We included the name of Southeast Asian countries and river basins and the generic terms:

'Blue green infrastructure' OR 'green infrastructure' OR 'natural infrastructure' OR 'nature-based solutions' OR 'river restoration' OR 'river rehabilitation'

together with specific types of BGI (e.g. 'raingarden', 'green roof', 'paddies', 'wetlands'), processes ('bioretention', 'biofiltration') and fields of research and practice ('watershed management', 'flood risk', 'water sensitive urban design', 'low impact development', Supplementary Information). 


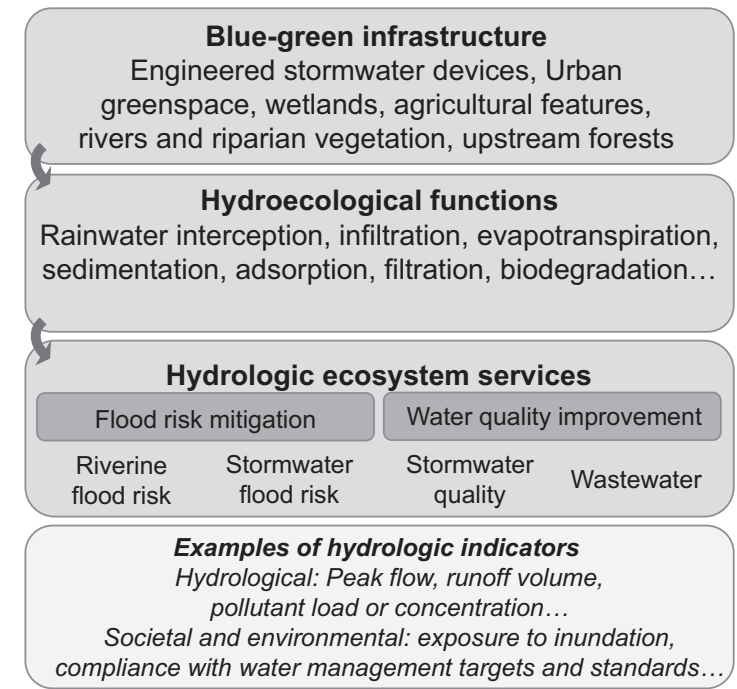

Fig. 1 Framework to study the performance of blue-green infrastructure on two hydrological ecosystem services in this study. Blue-green infrastructure performs several hydroecological functions that produce four key services. Additional services outside the scope of our review include coastal flood risk (by marine and coastal blue-green infrastructure) and water supply

We selected studies that (i) addressed at least one of the four services listed above, (ii) directly affected urban areas in Southeast Asia and (iii) provided evidence of the hydrologic performance of BGI or technical considerations for design and implementation. We also reviewed the grey literature, including reports and guidelines from websites of major conservation or development organisations, think tanks or multilateral banks, extracting information on implementation guidelines or hydrologic performance from regional case studies. Additional details on our search criteria and methods can be found in Supplementary Information.

\section{Types of BGI}

We classified the main types of BGI in four main categories used in previous research (Keeler et al. 2019; Liao et al. 2017): urban green space, engineered stormwater devices (including bioretention systems, bioswales, green roofs, retention and detention ponds), wetlands (constructed and natural) and watershed management features (forests, rivers and riparian vegetation and agricultural features) (Table 1). This categorization reflects the range of measures from watershed-scale (forests) to site-scale (engineered stormwater devices). In reviewing the literature, we paid specific attention to local types of BGI, including traditional architectural features. Such BGI specific to the region are of particular importance since they are likely to be more adequate and accepted in an inclusive approach to nature-based solutions (Frantzeskaki 2019).

\section{Hydrologic Performance}

For peer-reviewed literature, we extracted information on hydrologic performance, including commonly used indicators of peak flow, runoff volume reduction, pollutant removal efficiencies (total nitrogen, phosphorus and suspended solids-TN, TP, TSS - as well as biological oxygen demand, BOD, for wastewater). We distinguished between empirical data (including models with validation) and modelling results without validation, which typically have higher uncertainty, and systematically reported the former types of studies (Tables S3-S5). We also reported information on societal and environmental benefits (flood risk reduction, ecological improvement due to water quality improvements, Fletcher et al. 2013; Liao et al. 2017). Stormwater management best practices focus on mimicking the pre-development water cycle-reducing runoff volumes and increasing infiltration-to improve ecological impacts (Fletcher et al. 2013; Shuster et al. 2005). We therefore used the water budget at a watershed scale as a possible metric for ecological improvement. Additional metrics include compliance with standards (e.g. from the International Organization for Standardization) or guidelines (e.g. urban water management guidelines developed by government agencies). We also identified specific factors (e.g. vegetation type, climate) reported in the studies that may explain performance variability. Finally, we identified the studies that comprised hydrologic measurements as opposed to modelling studies with limited validation.

\section{BGI Design and Implementation Factors}

Barriers to BGI implementation include limited knowledge on implementation or effectiveness, limited physical space, weak and siloed governance, 'path dependency' or resistance to change and inadequate financial resources (Sarabi et al. 2020, 2019; Wamsler et al. 2020). Given our focus on hydrological performance, we focused on the first category - knowledge for implementation and effectiveness - and extracted information on four design factors of particular importance: consideration of grey infrastructure ('hybrid' infrastructure), climate change, co-benefits (i.e. benefits from BGI that are not related to their hydrological functions) and implementation in informal settlements.

\section{Results}

We compiled a list of 109 peer-reviewed papers (full list in Supplementary Information). Of the peer-reviewed papers, 51 addressed stormwater management, including 39 on stormwater quantity and 20 on quality, 42 papers addressed wastewater management, and 20 addressed riverine 


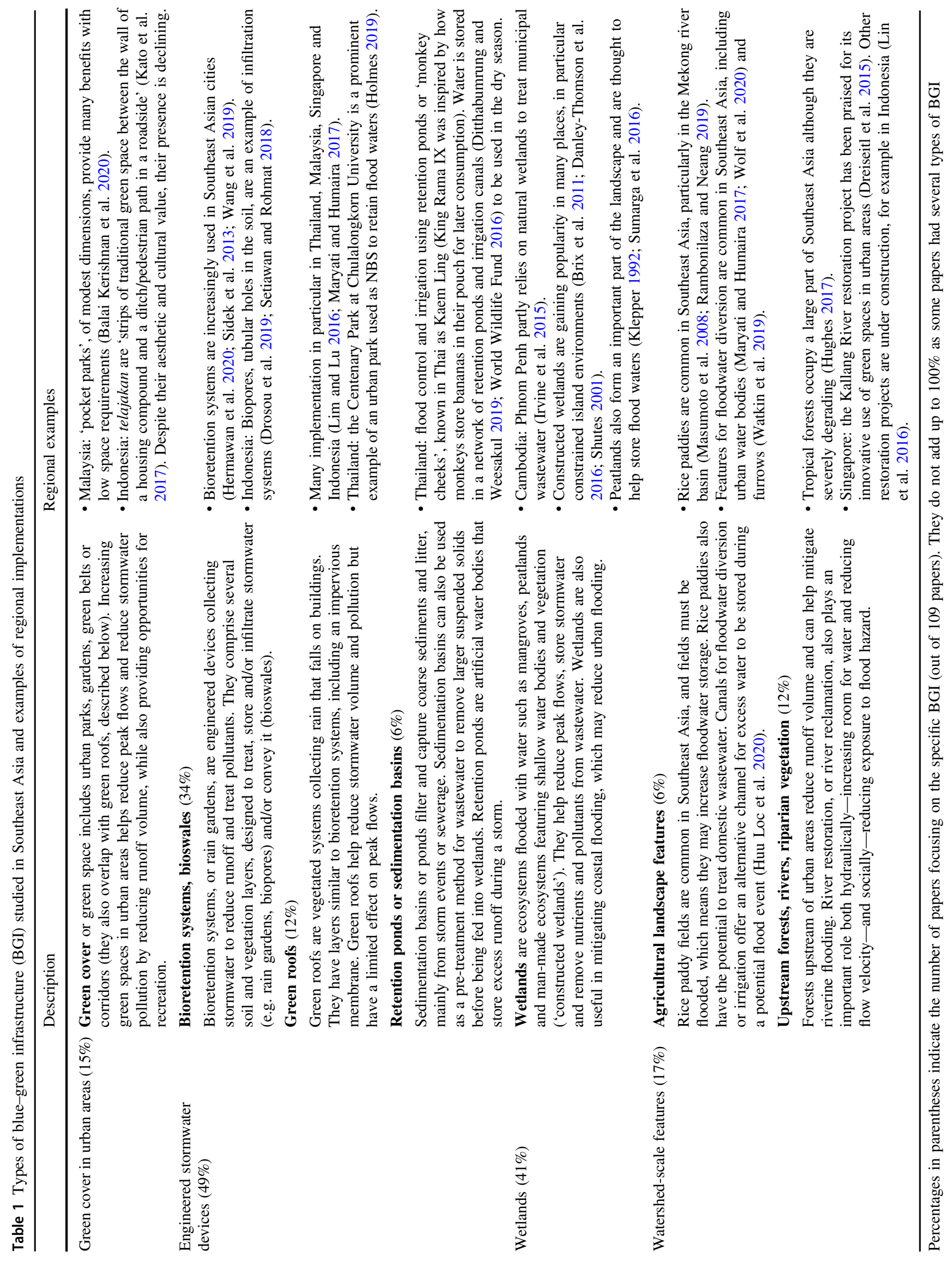




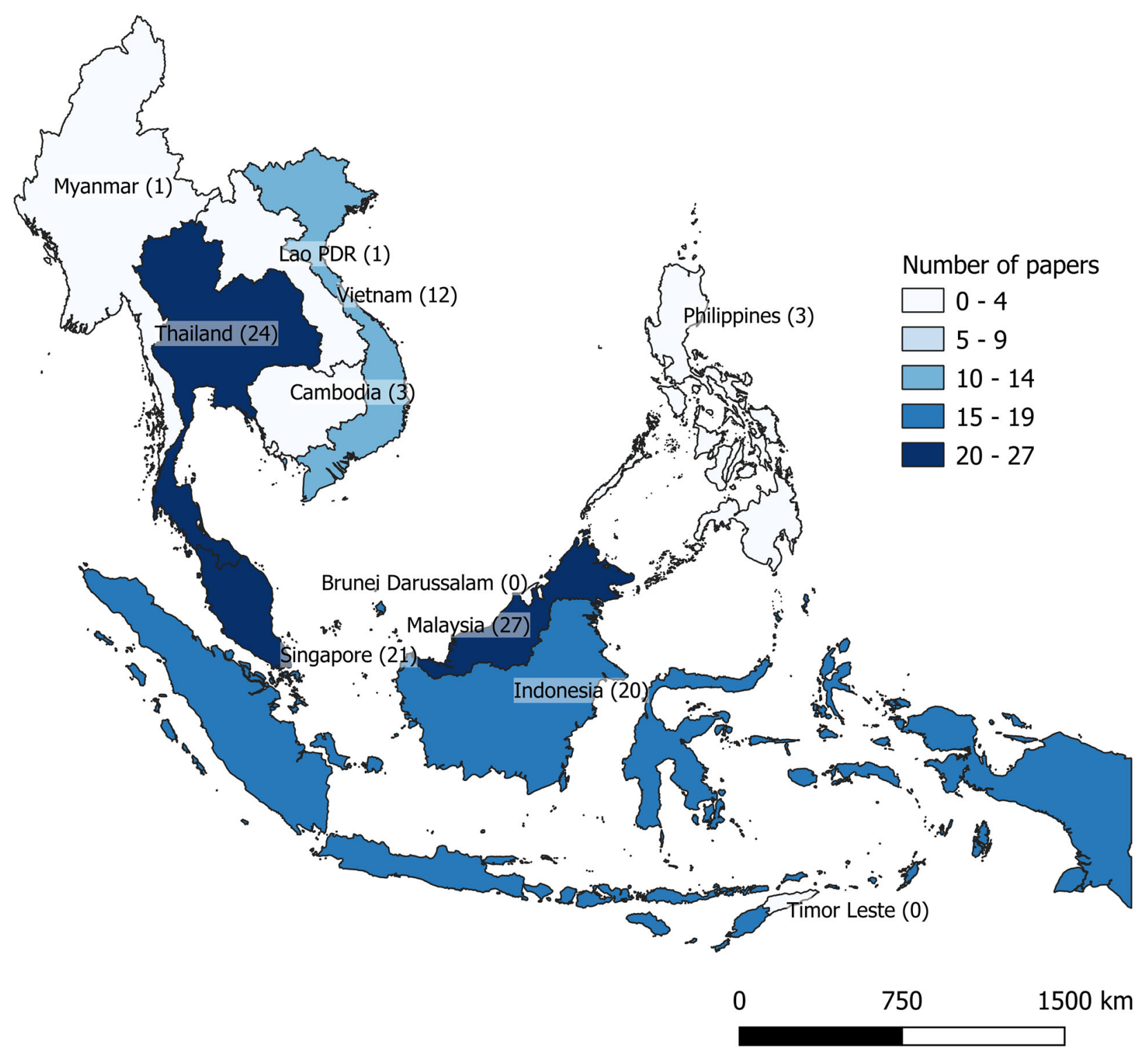

Fig. 2 Map of Southeast Asia colour-coded for number of publications found in our systematic search

flooding. In addition to the scientific literature, we listed 27 guidance documents in the 'grey' literature that represent an important source of information on BGI potential and implementation. For example, the Asian Development Bank's (2016) case studies on Nature-Based Solutions for Building Resilience in Towns and Cities detail the applicability of different types of BGI in the Greater Mekong subregion, including specific benefits and caution notes. Singapore's ABC Waters Programme and the AustraliaIndonesia Centre produced useful guidelines and detailed case studies (Payne et al. 2019; Public Utilities Board Singapore 2018). Technical and strategy reports also provide useful local lessons on BGI adoption for consideration in other Southeast Asian countries. The full list in
Supplementary information also comprises international guidelines applicable to the region (Browder et al. 2019; Colgan et al. 2017; World Bank 2016; World Wildlife Fund 2016).

\section{Types of BGI and Geographic Distribution of the Peer-reviewed Literature}

We found references to the four main categories of BGI described in Table 1 in the peer-reviewed literature. Engineered stormwater systems were the most-studied BGI ( $n=53$ ), closely followed by wetlands $(n=45$, including a majority of constructed wetlands), watershed management features $(n=19)$ and urban green cover $(n=16)$. Examples of 
regional implementations suggest that some types of BGI are specific to the region and therefore rarely found in the global North literature. These include some agricultural features (rice paddies), or architectural idiosyncrasies (telajakans in Bali, Indonesia, Table 1).

High- and upper-middle-income countries generally have the highest number of peer-reviewed publications (Fig. 2), and no publications were found for Timor Leste and Lao PDR. We found the highest number of publications related to flood management in Indonesia and Singapore $(n=25)$. Nearly half $(n=17)$ of the peer-reviewed publications on wastewater management were from Thailand, with most of them citing the need for wastewater management in cities affected by tourism.

\section{Hydrologic Performance}

\section{Riverine Flood Risk Reduction}

The most-studied type of BGI for riverine flooding was upstream forests. Research in the Ciliwung River, Indonesia and Kelantan River, Malaysia confirmed the effect of forests on peak flow attenuation-although the effect remained limited for large precipitation events (Abdulkareem et al. 2018; Asdak et al. 2018). In a modelling study, Asdak et al. (2018) found that the reduction of forested area from 58 to $34 \%$ in the Citarum watershed resulted in the increase of peak flow by around 14\%. Abdulkareem et al. (2018) investigated four river basins in Malaysia and found that (observed) peak flow increased by 8-39\% from 1984 to 2002 due to forest cover reducing by 19-59\%. In Thailand, Sriwongsitanon and Taesombat (2011) showed that forests reduce peak flow and runoff coefficients for small events but they can increase runoff coefficients-the ratio between runoff and precipitation-for large events. The authors explain this effect by the higher soil moisture retention in forests, increasing total runoff from large events occurring after a wet period. In a modelling study in the Tamontaka river basin, Philippines, Buisan et al. (2019) reported that forest conversion to agriculture by $22 \%$ would increase peak flow by about $10 \%$. None of the reviewed articles provided empirical evidence of the performance of forest restoration projects and many quantitative studies relied on uncalibrated model simulations (five of eight studies for upstream forests).

Despite the high potential of river restoration projects (Ozment et al. 2019), we found little evidence of such projects in Southeast Asia. In a modelling study, Lin et al. (2016) found that revegetation and implementation of retention basins along the Ciliwung River in Jakarta, Indonesia, would have a negligible effect on peak flow for the 2-year return flood, due to inability to store large volumes of water. Although implementation of BGI was less effective than grey infrastructure (canalization) from a hydraulic standpoint, it still reduced inundation extent in several settlements along the river. Recent projects such as the river corridor improvement project in the Klang River tributaries, Malaysia (cf. project reports in Supplementary Information), or the Kallang River project, in Singapore, could add to the evidence base although we found little monitoring data in the literature, as noted by others (Lim and Lu 2016).

A few studies quantified the role of paddies and irrigation systems in flood risk mitigation. Masumoto et al. (2008) established that paddies around the Tonle Sap lake could store up to $17 \%$ of the flood volume, and irrigation systems up to $42 \%$ in the lower lands, for a large flood event. Ditthabumrung and Weesakul (2019) found that irrigation systems, including in 'monkey cheeks' in Northern Thailand could effectively reduce flooding by creating more flood storage. Agricultural land areas in the watersheds upstream of Bangkok, in the Chao Phraya basin, seem to play an important role in delaying and reducing peak flow (Siripong et al. 2000). Although we did not find quantitative data, some researchers also highlight the role of peatlands, a type of wetland common in Southeast Asia, in water storage. Drainage of peatlands for cultivation may lead to subsidence and increase flooding both in the plantation and potentially downstream (Klepper 1992; Sumarga et al. 2016).

\section{Stormwater Flood Risk Reduction}

Studies examining stormwater flooding focused on engineered systems, mostly bioretention systems and retention ponds but also green roofs. Payne et al. (2019) compiled the evidence and guidelines for the implementation of engineered systems in Bogor, Indonesia, which are relevant to most Southeast Asian cities. The authors highlight that empirical evidence in the region is scarce-only a few studies are cited to quantify the hydrological performance of stormwater systems-but they compile a useful list of existing resources to design engineered systems in the region (see Supplementary Information).

In Singapore, a review conducted by Lim and Lu (2016) concluded that systems in the Active Beautiful Clean (ABC) Waters programme, an initiative promoting BGI for water management in the country, provide average runoff retention performance for engineered devices. The authors conclude that there limited empirical evidence of the hydrologic performance of new BGI features implemented in the country. They also provide technical recommendations, e.g. that bioretention systems and wetlands should be designed to mitigate at least low magnitude flood risk (1year flood event). Additional evidence from recent studies suggests that a bioretention system designed according to the $\mathrm{ABC}$ Waters programme guidelines could reduce peak 
flow by an average of $94 \%$ (Wang et al. 2017). Trinh and Chui (2013) found that a combination of green roof and bioretention systems can return peak runoff to preurbanisation levels, while Wang et al. (2018) found that up to $75 \%$ could be retained in bioretention cells. Peak flow was also reduced by $63 \%$ in a study by Goh et al. (2017); and by $33 \%$ in a study by Yau et al. (2017) (10-year average recurrence interval). Outside Singapore, we found other studies confirming the retention performance of BGI in a tropical climate, and sometimes in low permeability soils, with examples in Malaysia (Lai and Mah (2012); Rezaei et al. (2019)); Indonesia (Setiawan and Rohmat (2018)); Vietnam (Loc et al. 2015) and Thailand (Chaosakul et al. 2013; Majidi et al. 2019). Overall, we found empirical evidence of runoff volume retention by engineered systems ranging from 1 to $100 \%$, with the low values corresponding to high intensity events (Table S3).

Among the factors explaining hydrological performance, rainfall intensity was examined in a few studies, with higher intensity leading to lower BGI efficiency (e.g. Azkarini et al. 2019; Majidi et al. 2019; Yau et al. 2017). However, evidence confirms that with appropriate design, BGI can reach high retention performance as illustrated in the studies cited above. To address local climate conditions, Yau et al. (2017) propose a revision of the design guidelines to consider runoff volume instead of the more traditional average recurrence interval (e.g. 3-month return), since the latter does not adequately capture the wide range in rainfall intensity in the Tropics.

We found little information on the type of vegetation that might increase retention and most studies use default parameters from non-tropical countries (e.g. for engineered systems in Majidi et al. (2019) or land use in Goh et al. (2017)). There was also limited information on long-term maintenance. Ong et al. (2012) found that some plant species may require manual irrigation, contrasting with water quality guidelines on plant selection (see next section). We did not find any information on the interactions between stormwater and riverine or coastal flooding.

\section{Stormwater Quality Improvement}

Engineered systems are commonly used to manage stormwater quality, in particular bioretention cells, with 14 out of the 21 reviewed studies on stormwater quality including this type of BGI. In their review focused on Singapore, Lim and $\mathrm{Lu}$ (2016) found low nutrient removal and leaching from rain gardens and constructed wetlands, but a good performance for TSS removal. Ong et al. (2012) and Wang et al. (2017) also found that TN and TP removal rates were lower in Singapore, due to insufficient storage capacity, leading to overflow, and incomplete denitrification. Compared to other countries, stormwater runoff in Singapore seems relatively low in nutrient content. Sim et al. (2008) found a good nutrient removal performance, up to $82 \%$ for TN and $83 \%$ for TP, of the Putrajaya constructed wetland, confirmed by laboratory studies. They note the lower performance during periods of heavy rains and the role of evapotranspiration in increasing nutrient concentration, which should inform the design of future wetlands. Green roofs also receive increasing attention for their role in reducing runoff, hence reducing stormwater quality issues (Chai et al. 2017; Kok et al. 2013), but also potential disservice (increasing nutrient loads, Vijayaraghavan et al. 2012). One study assessed the performance of a floating wetland (TN removal rates ranged from 7 to 67\%), suggesting that this type of BGI has some potential to improve water quality in reservoirs (Chua et al. 2012). Despite an emerging body of literature examining optimal design and maintenance options of these systems, studies often call for more research on the performance of floating wetlands systems or innovative combinations of engineered systems in the Tropics ( $\mathrm{Lim}$ and $\mathrm{Lu}$ 2016). Overall, we found empirical data for TSS removal ranging from 53 to $92 \%$, TN removal from 25 to $82 \%$ and TP removal from 21 to $83 \%$ (Table S4).

Plant selection plays an important role in removal rates of engineered systems, and Hermawan et al. (2020) found that three native plant species could survive well and reach high treatment removal performance. A number of laboratory studies are available to guide plant selections, including a comprehensive study in Singapore (Loh 2012; Loh and Hunt 2013), and Australian studies reviewed by Payne et al. (2019).

\section{Wastewater Quality Improvement}

A large majority (33 of 40) of the reviewed papers on wastewater treatment use small-scale prototypes to determine the suitability of various plants for pollutant removal in constructed wetlands. For example, constructed wetlands planted with canna and heliconia were shown to have similar removal efficiencies, although canna grew better in domestic wastewater (Qomariyah et al. 2018). Other examples include the use of cocopeat (Danley-Thomson et al. 2016), reed and vetiver grasses (Nguyen et al. 2020) or rice (Kantawanichkul et al. 2003). Mangrove plantations were also investigated by Boonsong et al. (2003), who found that plantations provided similar treatment to existing mangrove forests $(45-54 \%$ and $23-65 \%$ removal, respectively, for TN and TP). Several studies also examined other design options, e.g. roof wetland (Bui et al. 2014), or different feeding strategies ( $\mathrm{Ni}$ et al. 2013).

Optimal design options for different types of effluents have been tested, such as domestic (Engida et al. 2020; Salih et al. 2017; Koottatep et al. 2001; Liamlaem et al. 2019), municipal landfill leachate in Thailand and Malaysia 
(Akinbile et al. 2012; Ogata et al. 2015; Sawaittayothin and Polprasert 2007), industrial effluent from the batik industry in Indonesia (Effendi et al. 2018; Rahmadyanti et al. 2020), seafood industry in Thailand (Yirong and Puetpaiboon 2004) or palm oil industry in Malaysia (Sa'At et al. 2019; Ujang et al. 2018), biochemical effluent (Meutia 2001; Vo et al. 2019) or agricultural wastewater in Malaysia and Thailand (Kantawanichkul et al. 2003; Liang et al. 2017; Pongthornpruek 2017). Studies in Singapore and Thailand also examined the role of constructed wetlands for pharmaceutical removal (Vo et al. 2019; Zhang et al. 2015, 2012). Only three studies examined the role of wetlands for greywater treatment: a horizontal flow wetland in treating greywater in Indonesia (Qomariyah et al. 2018), and two case studies in Thailand (Brix et al. 2007; Liamlaem et al. 2019), which all confirmed that wetlands could effectively treat water for non-potable reuse (Payne et al. 2019).

Only a limited number of papers studied full-scale systems, mainly in Thailand (Brix et al. 2011, 2007; Møller et al. 2012), Malaysia (Shutes 2001), Vietnam (Trinh et al. 2013) and Cambodia (Irvine et al. (2015). Among those, two constructed wetlands in Thailand provided nitrogen removal rates of 38 and $86 \%$, and biological demand reduction by 72 and $87 \%$ (Brix et al. 2011; Møller et al. 2012). This may reflect the low number of constructed wetlands for wastewater management, as the grey literature also has few examples (the majority of wetlands in the grey literature were studied for coastal flood protection).

\section{Societal and Environmental Benefits of BGI}

Most of the reviewed papers assessed the biophysical functions of BGI, i.e. peak flow reduction, water retention and pollutant removal efficiency. Only a few studies examined the societal and environmental benefits-i.e. the actual (hydrologic) services (Fig. 1, bottom row). Few studies reported the effect of BGI on the water cycle, in part because many of them were conducted at the site scale. With regard to flood risk mitigation, studies rarely looked at the effect of BGI on inundation. Some exceptions include the study by Kefi et al. (2018), who found that the implementation of bioretention systems could reduce inundated areas by $59 \%$ and losses by $29 \%$ in an urban watershed in Vietnam. Analyzing 16 years of flood data in 31 basins in Malaysia, Tan-Soo et al. (2016) found robust evidence on the link between forest conversion to oil palm and rubber plantation and occurrence of flooding. Using an econometric approach, they estimate the effect of inland forest conversion to oil palm on number of days flooded, potential additional deaths and evacuations. Majidi et al. (2019) presented a map of inundation in a neighbourhood of Bangkok, Thailand although they expressed their modelling results as runoff volume and peak flow reduction, not flood impact. Pre-urbanisation peak flow may be used as a reference to show that the increase in flood hazard due to urbanisation has been mitigated, as demonstrated by Trinh and Chui (2013) in their study of a mix of green roof and bioretention systems. For water quality, certifications specifying acceptable effluents levels can be used a benchmark for BGI implementation. They were used in one study of domestic wastewater treatment by constructed wetlands in Sakon Nakhon, Thailand, showing that the wetlands were maintained and effective after 13 years of implementation and obtained the ISO9001 certification (Liang et al. 2017). Studies in Singapore also regularly refer to the ABC Waters guidelines.

Only a few studies report the economic value of BGI to inform the economic and financial feasibility of future projects. Agus et al. (2006) through a replacement cost approach, valued the retention service of paddies in the Citarum watershed, Indonesia, at USD 92.67 million per year or $51 \%$ of the total price of rice produced in the field. Ro et al. (2020) valued the water treatment service of a wetland in Phnom Penh, Cambodia, at about USD 3 million per year. Goh et al. (2017) found that every SGD10,000 of BGI features incorporated can reduce the runoff coefficients (e.g. by from $0.25 \%$ in green roofs to $3.5 \%$ in porous pavements).

\section{Design and Implementation Factors for BGI}

\section{Combining Grey Infrastructure and BGI}

We found little information on mixed (BGI and grey infrastructure) systems, and even less on the optimal combination of BGI and grey infrastructure. Ditthabumrung and Weesakul (2019) proposed a method to quantify the effectiveness of flood management in the Rangsit area in Bangkok, Thailand, including both grey infrastructure (concrete canals) and BGI (retention ponds). Although they quantified the effectiveness of the infrastructure mix, the study does not assess the respective contribution of each type or potential synergies increasing overall effectiveness. In Vietnam, Nguyen et al. (2020) found that expanding pipes was more effective at reducing stormwater volumes than implementing green roofs. In their evaluation of Singapore's ABC Waters Programme, Lim and Lu's (2016) examine the combined effect of grey infrastructure (canals and drainage system) and BGI. This follows the Public Utilities Board's guidelines that only recommends that the overall performance of the system is reported. Combining BGI and grey infrastructure was more common in wastewater treatment systems. For example, domestic wastewater in Can Tho and Ho Chi Minh, Vietnam is passed through a septic tank before being treated in wetland systems (Tran 
et al. 2019; Zhang et al. 2012). In this case, the differentiation between the impacts of the grey infrastructure (septic tanks) and BGI (wetlands) is easily evaluated separately since water samples were tested for pollutants concentrations before and after each step.

\section{Considering Future Climate}

The vast majority of studies (94\%) did not address climate change or simply mentioned that future climate may exacerbate existing urban water management problems. A notable exception is Wang et al.'s $(2016,2017)$ simulations of the effectiveness of bioretention in Singapore, which account for different future climate scenarios derived from representative concentration pathways (RCPs). By simulating several shared socio-economic pathways and RCPs for a hypothetical catchment in Singapore, they found that the impacts of urbanization were more 'adverse than that of climate change'. Kefi et al. (2018) also examined the impacts of climate change on flood risk in Hanoi, Vietnam, and found that total damage from floods may increase by $26 \%$ and inundated areas by $19 \%$ under future climate. Wolf et al. (2020) also examined the demand for ecosystembased adaptation based on perceived consequences of natural hazards and climate change. Saltwater intrusion and increased frequency and intensity of floods and droughts were key concerns of local unions and policymakers, leading to high demand for BGI such as mangroves.

\section{Assessing Co-benefits}

Only a few studies in our review considered co-benefits despite their importance in integrated urban water management. Majidi et al. (2019) assessed the effectiveness of various nature-based solutions based on a range of criteria covering both hydrologic and urban cooling services. Meerow (2019) examined synergistic 'hotspots' that maximise co-benefits in Manila and found that the stormwater management service correlated positively with three other services: reducing social vulnerability, reducing the urban heat island effect and improving air quality. Other authors have examined which co-benefits should be prioritised. Balai Kerishnan et al. (2020) surveyed users and non-users of 'pocket parks' in Malaysia and found that beyond the hydrological ecosystem services, the most valued cobenefits were stress reduction and provision of a resting space. Alves et al. (2018), with a survey of stakeholders in the Sukhumvit area of Bangkok, Thailand, found that all major stakeholder groups prioritised aesthetics and amenities, but the general public and policymakers placed rainwater harvesting in their top priorities while the scientific community most valued the presence of biodiversity and ecology.
Finally, some authors examined the use of stormwater or wastewater resources for agriculture (Trinh et al. 2013). Most studies and standards caution against the use of stormwater irrigation for gardening (WHO 2017; Payne et al. 2019). Yet they also highlight the potential of this practice with careful crop selection and soil management (Payne et al. 2019, Tom et al. 2014). Ogata et al. (2015) found that rice paddies designed as a wetland filtration system for domestic wastewater could successfully reduce phosphorus and nitrogen levels to meet Thai water standards without compromising the quality and quantity of the rice crops yielded.

\section{BGI in Informal Settlements}

Although there are examples illustrating the potential benefits of rain gardens, riparian vegetation or constructed wetlands around the world (du Toit et al. 2018; Mononimbar 2018), we found very few examples in Southeast Asia. An interesting initiative from the RISE $^{1}$ program aims to demonstrate the application of the water sensitive urban design principles, including the reliance on green infrastructure, to informal settlements in Fiji and Indonesia (Fig. 3). Recent reports from the programme provide examples of engineered systems BGI that are appropriate in informal settlements, and propose a roadmap for leapfrogging (Ramirez-Lovering et al. 2019; Rogers et al. 2019). The researchers recommend mainstreaming of lab testing and field piloting of systems in local conditions. Such recommendations would apply to other examples from practice, such as WetlandsWork ${ }^{2}$ in Cambodia, which confirm an interest in nature-based solutions in the region, without necessarily building the knowledge base due to limited resources for testing and monitoring.

\section{Discussion}

\section{Scope of the Literature and Limitations of the Review}

Not surprisingly, the number of peer-reviewed publications in the region (109) is low compared to the global average: a review by Venkataramanan et al. (2019) found that there were more than 4500 papers on BGI for flood and stormwater management worldwide to be contrasted with 50 papers on BGI in our initial search (Table S2, Supplementary information). Our review suggests that the majority of the scientific knowledge on BGI in Southeast Asia

\footnotetext{
1 https://www.rise-program.org/

2 https://wetlandswork.com/products-and-services/sanitation-in-cha

llenging-environments/flood-prone-sanitation-design/)
} 


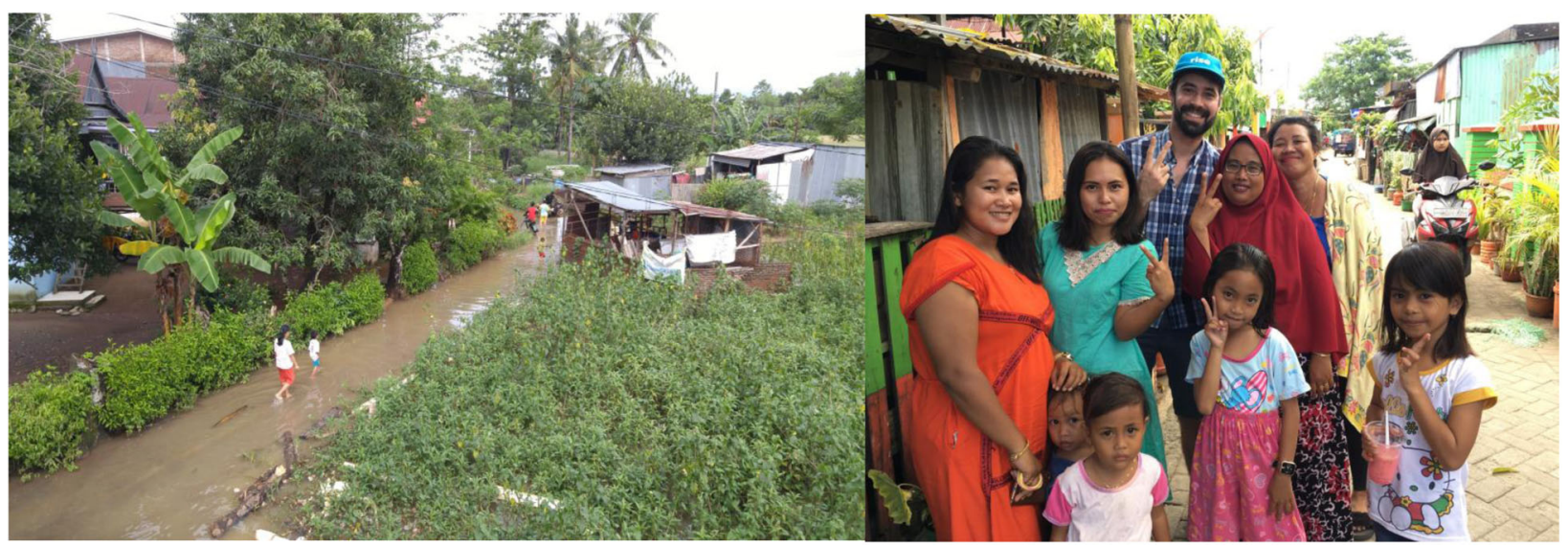

Fig. 3 Despite the prevalence of informal settlements in Southeast Asia, there is still a limited understanding of the most appropriate types of natural infrastructure in these environments. Credit: The

emerges from four of the five wealthier countries in the region (measured by GDP/capita): Singapore, Malaysia, Thailand and Indonesia. This regional disparity mirrors a global trend, suggesting that most of the research on BGI emanates from wealthier countries in the global North (Keeler et al. 2019) and was confirmed by a recent review on urban ecosystem services in Southeast Asia (Lourdes et al. 2021). We found that $40 \%$ (21 of 52) of the publications with reported sources of funding had funding from wealthier nations outside the region. This suggests that funders have the potential to reduce the geographic bias by privileging research focusing on low-income countries.

An important finding from the review was that most of the reviewed papers focused on engineered systems (including man-made wetlands) for stormwater and wastewater management, with little information on watershedscale measures such as forests and rivers upstream of cities. The paradigm shift in urban water management observed globally may explain the amount of research on engineered systems (Brears 2018; Fletcher et al. 2015; Liao et al. 2017; Shuster et al. 2005). The shift promotes a holistic approach to urban water management aiming to mimic the water cycle of a watershed prior to urban development — often relying on engineered systems such as man-made wetlands or bioretention systems (Fletcher et al. 2013; Liu and Jensen 2018). However, our finding points to some blind spots in the integrated watershed management framework. A systemic perspective of the entire watershed, including peri-urban and rural areas, is a critical component of the new urban water management paradigm but this was not apparent in the reviewed studies. Another reason for the bias towards smallscale systems is their lower costs, and hence popularity. Larger river restoration projects, for example (e.g. BishanAng Mo Kio park in Singapore, Dreiseitl et al. 2015), require much larger amount of capital, political will and agency coordination that make them less common.
Revitalising Informal Settlements and their Environments program (RISE; Erich Wolff and Noor Ilhamsyah)

Although we found some mention of local types of BGI (e.g. 'monkey cheeks' in Thailand, biopores and telajakans in Indonesia, and rice paddies throughout the region), there is still limited information available on those BGI that are not found in the global North. Lack of knowledge on their role and hydrological performance points to a missed opportunity since these local features are likely to be important in inclusive planning (Frantzeskaki 2019). This is particularly true for rice paddies and urban agriculture, which has potential in Southeast Asia (Agus et al. 2006; Ramirez-Lovering et al. 2019). Given the abundance of rice farming in Southeast Asia-31\% of rice harvested globally (Redfern et al. 2012) - the potential of rice paddies both for irrigation water supply and wastewater treatment warrants further investigation. Peri-urban forests also received relatively little attention, which contrasts with the flourishing literature on urban growth and its impacts on ecosystem services (McDonald et al. 2020; Richards et al. 2017).

To contextualize these findings, we note the limitations of the systematic search of the scientific literature. First, our search was limited to English-only literature and references in the Web of Knowledge database. Second, search terms targeted Southeast Asian countries and some studies may not indicate the name of the country or river basin forming part of our search terms (although the indexing system of the Web of Knowledge database minimizes this bias, cf. Supplementary Information). Third, search terms focused on BGI (Search 1, Supplementary Information) and may exclude papers that focused on specialized fields (e.g. stormwater management). Searches with specific types of BGI (e.g. 'rain gardens', 'paddies') aimed to compensate for this bias and added a significant amount of papers. The selection of search terms is notoriously challenging in the field of BGI given the large amount of overlaps in concepts (e.g., nature-based solutions, green infrastructure, water sensitive urban 
design, Moosavi et al. 2021; Fletcher et al. 2015). Our search focused on structural elements, although we note that a more deliberate selection of search terms may improve future reviews, especially those with a focus on planning and implementation (see for example the selection process proposed by Adem Esmail and Suleiman 2020). Overall, our systematic search allowed us to retrieve a representative range of papers but does not reflect the full breadth of the scientific production in the region. For example, our review excludes fundamental knowledge relevant to BGI performance, e.g. the emerging amount of research on pharmaceutical pollutant removal in tropical conditions (e.g. Li et al. 2020).

\section{Hydrologic Performance}

Our review confirms the role that BGI can play in urban water management by helping mitigate floods, and treat stormwater and wastewater, in line with the global literature (Fletcher et al. 2015; Liao et al. 2017; Liu and Jensen 2018; Oral et al. 2020; World Bank 2016). For flood mitigation, forest management has the potential to reduce flood risk by reducing peak flows by modest amounts (although up to $39 \%$ in the studies reviewed here). This confirms the global evidence that forests reduce flood volume and peak flows (Andreassian 2004; Bradshaw et al. 2007), with the caveat that their effect is limited, or even negative (Sriwongsitanon and Taesombat 2011), for large flood events, when soil saturation capacity is reached. Importantly, even modest reductions in peak flows can have important consequences in highly exposed areas (Lallemant et al. in press). The effect of engineered systems can be more significant, especially for low intensity and frequent flooding in cities, with multiple studies reporting significant amount of reduction from bioretention systems, up to $95 \%$ (see Table S3, Supplementary Information). Because these systems are engineered, they can also address large flooding events given enough storage space (e.g. through retention basins).

For water quality, engineered systems including constructed wetlands and bioretention systems show removal rates above $80 \%$ for TN and TP (Table S4, Supplemenatry Information), which is above the recommendations from the ABC Waters programme guidelines, themselves derived from Australian guidelines (Public Utilities Board Singapore 2018). However, limited storage capacity leads to lower rates as reviewed by $\mathrm{Lim}$ and $\mathrm{Lu}$ (2016). Plant selection and design guidelines are now available from recent efforts in Singapore and Australia (Loh 2012; Payne et al. 2019). Almost two thirds (28 of 43) of the evidence for flood reduction comes from modelling studies with limited validation, which questions the evidence base (Brauman 2015). Water quality research was more empirical with the majority ( $71 \%$ of the stormwater quality papers) comprising observed data. For wastewater management, however, empirical data are available for pilots but monitoring of full-scale wetlands remains scarce, reflecting the nascent interest in this type of BGI in the region.

Although information on the hydrological performance of BGI is valuable to water specialists (e.g. stormwater engineers), information on societal and environmental benefits is also needed to mainstream the use of BGI in other professions, e.g. landscape architecture and urban design (Huu Loc et al. 2020). This is particularly true to foster engagement in participatory approaches, as described by some studies in the region (Drosou et al. 2019; Laituri 2020; Møller et al. 2012; Wolf et al. 2020). Yet most scientific papers focus on hydrological functions, overlooking the range of economic or other societal benefits. This blind spot may reflect the infancy of the field-economic valuation studies, in particular, are much more common outside Southeast Asia (US-EPA 2013; World Bank 2017; Gunawardena et al. 2017). It also confirms recent observations in the global literature that there is insufficient consideration of the human health impacts of BGI for stormwater and flood management (Venkataramanan et al. 2019).

\section{Design and Implementation Factors for BGI}

Recent studies have identified insufficient knowledge on implementation or effectiveness as a key challenge to BGI adoption (Sarabi et al. 2020, 2019; Wamsler et al. 2020). In our review of the scientific literature, there was little information on combined grey and BGI systems (and more generally watershed-scale effects), climate change effects, and co-benefits, and informal settlements, with only a dozen studies reported in 'Design and Implementation Factors for BGI'. We elaborate on these factors in identifying key knowledge gaps in the next section and discuss here why such information is needed for BGI implementation. Studies of combined grey and BGI are important to optimize the implementation of BGI, understanding the location and extent to which BGI can benefit urban water management (e.g. Ditthabumrung and Weesakul 2019; Yi et al. 2020). They can be easily incorporated in ecosystem services assessments to inform urban planning (Adem Esmail and Geneletti 2020; Depietri and McPhearson 2017; Lourdes et al. 2021). Co-benefits of BGI were also poorly considered, while international evidence suggests that they are an important part of the value of BGI and critical to adoption (Frantzeskaki 2019; Keeler et al. 2019). International studies suggest that climate change will reduce the magnitude of hydrologic services (Runting et al. 2017) so regional knowledge should be built to better consider longterm impacts. However, only $6 \%$ of the studies incorporated climate change in a quantitative way. Incorporating future climate scenarios in studies is important as the effects of 
climate change may already be seen in Southeast Asia. For example, an increasing trend in maximum hourly rainfall intensities observed in Singapore $(\sim 20 \%$ from 1980 to 2012; Yau et al. 2017).

Finally, ecosystem-based management in upgrading informal settlements may contribute to climate adaptation through providing cool spaces and increasing water-related services provided by BGI (Satterthwaite et al. 2020). Yet this opportunity remains a frontier of knowledge and lessons from recent projects are only emerging (e.g. RISE programme, cf. 'Design and Implementation Factors for BGI'). Evidence outside Southeast Asia suggests that challenges to BGI implementation in informal settlements reflect those in formal areas in cities (Sinharoy et al. 2019). Are highlighted in particular factors related to limited understanding and lack of relevant valuation data on BGI, lack of capacity and expertise, financial barriers, weak governance, lack of baseline data, perception of disservices, limited space competing with other land uses and low climate adaptation capacity (du Toit et al. 2018; Mulligan et al. 2020). Yet scholars note the potential of BGI in socalled leapfrogging strategies, whereby developing countries adopt more advanced water management approaches that avoid issues that developed economies have experienced (e.g. centralized drainage system that reduces water retention services) (Rogers et al. 2019). Further research will help understand the hydrological performance, socioeconomic benefits and implementation challenges and opportunities through understanding local governance contexts (Diep et al. 2019; Mulligan et al. 2020; Sinharoy et al. 2019).

\section{Key Knowledge Gaps}

Our discussion highlighted several knowledge gaps and research needs (Table 2). First, there is an urgent need for more empirical data on large-scale effects of BGI to complement and support modelling studies on both flood hazard and water quality issues. This is true for studies examining the effect of the implementation of BGI at the watershed scale, which are notoriously difficult to conduct (Lim and Lu 2016; Walsh et al. 2015), but also for simpler experimental designs comparing watersheds with varying levels of BGI (e.g. comparing land use (Abdulkareem et al. 2018; Asdak et al. 2018)). Such studies would provide evidence to support the debates on the effect of deforestation on flooding, revived for example by the Kalimantan 2021 floods in Indonesia.

Second, some types of BGI are understudied in the scientific literature especially when compared to the breadth of nature-based solutions promoted in the grey literature. Riparian vegetation and river restoration projects are poorly studied in Southeast Asia, despite their potential importance 
for flood risk mitigation. Rice paddies and urban agriculture, in the form of community gardens or peri-urban individual plots, also require more attention.

Third, engineered systems (e.g. bioretention, green roofs) need to be studied over long term to better understand the decline in performance and maintenance requirements. Issues like clogging, for example, are important considerations for long-term success of engineered systems (Fletcher et al. 2013). More research on the role of greywater is also recommended by some guidance documents, in particular for peri-urban and informal areas. Long-term hydrological impacts should be more routinely translated into societal and environmental impacts to better evaluate their benefits.

Fourth, there is insufficient information for practical design and implementation of BGI. For example, scenarios combining BGI and grey infrastructure or different levels of implementation of BGI would help understand investments needs. Scenarios could also examine other drivers of floods, e.g. subsidence or sea-level rise to understand the potential of BGI under such circumstances. In general, studies should more systematically consider future climate in the experimental design or interpretation of their results, guided by frameworks used by practitioners (e.g. ADB guidelines in Supplementary information). Societal costs and benefits, including additional urban ecosystem services (e.g. heat mitigation) should also be further examined to understand synergies and leverage the multifunctionality of BGI.

Finally, despite the prevalence of informal settlements in the region, a better understanding of the type of BGI recommended in different types of settlements is crucial. Recent initiatives on the potential for leapfrogging of such settlements pave the way for such action research (Rogers et al. 2019). As noted earlier, understanding not only the hydrologic performance but also the local implementation challenges and opportunities is crucial (Diep et al. 2019; Mulligan et al. 2020; Sinharoy et al. 2019). An improved conceptual framing of formal and informal urban water infrastructure (e.g. Adem Esmail and Geneletti 2020) and collaborative work with civil society and NGOs, in particular through upgrading initiatives, will catalyze relevant and legitimate research projects in this field (Satterthwaite et al. 2020).

\section{Conclusions}

In summary, there is evidence of uptake of the concept of BGI for urban water management in research and practice in most countries. With a systematic search focusing on hydrologic performance, we found 109 papers, which should be seen as a lower bar for estimating the total amount of the evidence in the region. These scientific publications also map a network of research institutes, which actively create new knowledge in the region.

Our review confirms that the general principles behind BGI performance apply to Southeast Asian ecological context (climate, vegetation), meaning that there are no technical barriers to using BGI in integrated urban water management in the region. However, there is limited information to design new projects, in part due to a limited amount of empirical data in the region (a majority of studies used models without empirical data or were laboratory studies or prototypes). Factors that need particular attention from a design perspective include climate change, longterm maintenance, combination with grey infrastructure and considerations of BGI that are not studied in the North (e.g. rice paddies) or that are adequate in informal settlements (due to limited space, built infrastructure, or financial resources). We propose directions for research including short- and long-term monitoring programmes, and increasing collaborations with practitioners and ecosystem services scientists, to realize the potential of BGI in the region.

Given the ecological similarities within countries, there are ample opportunities for knowledge transfer within the region. This transfer can take the form of peer-reviewed publications, grey literature (e.g. the ABC Waters programme guidelines or the recent work from the AustraliaIndonesia Centre, Payne et al. 2019), conferences and also educational programmes. Similar to international research programmes in the European Union or the United States, coordinated research could significantly increase the body of evidence by leveraging existing efforts and accelerate the mainstreaming of BGI in urban water management in the region.

\section{Data Availability}

The list of papers reviewed in the article is available in supplementary information.

Acknowledgements We thank Kim Irvine and three anonymous reviewers for their precious comments on this manuscript.

Author Contributions PH oversaw the research, conceptualized the review, selected and reviewed the papers, wrote the initial draft and edited the manuscript. LT selected and reviewed the papers, edited the manuscript and wrote the supplementary information.

Funding This research was supported by the Singapore National Research Foundation (NRF-NRFF12-2020-0009) and Nanyang Technological University, Singapore.

\section{Compliance with Ethical Standards}

Conflict of Interest The authors declare no competing interests. 
Publisher's note Springer Nature remains neutral with regard to jurisdictional claims in published maps and institutional affiliations.

Open Access This article is licensed under a Creative Commons Attribution 4.0 International License, which permits use, sharing, adaptation, distribution and reproduction in any medium or format, as long as you give appropriate credit to the original author(s) and the source, provide a link to the Creative Commons license, and indicate if changes were made. The images or other third party material in this article are included in the article's Creative Commons license, unless indicated otherwise in a credit line to the material. If material is not included in the article's Creative Commons license and your intended use is not permitted by statutory regulation or exceeds the permitted use, you will need to obtain permission directly from the copyright holder. To view a copy of this license, visit http://creativecommons. org/licenses/by/4.0/.

\section{References}

Abdulkareem JH, Sulaiman WNA, Pradhan B, Jamil NR (2018) Relationship between design floods and land use land cover (LULC) changes in a tropical complex catchment. Arab J Geosci 11:376. https://doi.org/10.1007/s12517-018-3702-4

Adem Esmail B, Geneletti D, Adem Esmail B, Geneletti D (2020) Linking ecosystem services to urban water infrastructures and institutions BT-ecosystem services for urban water security: concepts and applications in Sub-Saharan Africa. Springer International Publishing, Cham, p 7-21. https://doi.org/10.1007/ 978-3-030-45666-5_2

Adem Esmail B, Suleiman L (2020) Analyzing evidence of sustainable urban water management systems: a review through the lenses of sociotechnical transitions. Sustain. https://doi.org/10. 3390/su12114481

Agus F, Irawan I, Suganda H, Wahyunto W, Setiyanto A, Kundarto M (2006) Environmental multifunctionality of Indonesian agriculture. Paddy Water Environ 4:181-188. https://doi.org/10. 1007/s10333-006-0047-5

Akinbile CO, Yusoff MS, Ahmad Zuki AZ (2012) Landfill leachate treatment using sub-surface flow constructed wetland by Cyperus haspan. Waste Manag 32:1387-1393. https://doi.org/10.1016/j. wasman.2012.03.002

Alves A, Patiño Gómez J, Vojinovic Z, Sánchez A, Weesakul S (2018) Combining co-benefits and stakeholders perceptions into green infrastructure selection for flood risk reduction. Environments 5:29. https://doi.org/10.3390/environments5020029

Andreassian V (2004) Waters and forests: from historical controversy to scientific debate. J Hydrol 291:1-27. https://doi.org/10.1016/j. jhydrol.2003.12.015

Asdak C, Supian S, Subiyanto (2018) Watershed management strategies for flood mitigation: a case study of Jakarta's flooding. Weather Clim Extrem 21:117-122. https://doi.org/10.1016/j.wa ce.2018.08.002

Asian Development Bank (2019) Nature-based solutions for cities in Viet Nam: water sensitive urban design

Asian Development Bank (2016) Nature-based solutions for building resilience in towns and cities: case studies from the Greater Mekong Subregion

Azkarini L, Anggraheni E, Sutjiningsih D (2019) The influence of low impact development-best management practices implementation on surface runoff reduction: a case study in Universitas Indonesia catchment area. Proceedings of the MATEC Web of Conferences, vol 276. p 04007. https://doi.org/10.1051/matecconf/201927604007

Balai Kerishnan P, Maruthaveeran S, Maulan S (2020) Investigating the usability pattern and constraints of pocket parks in Kuala
Lumpur, Malaysia. Urban For. Urban Green 50:126647. https:// doi.org/10.1016/j.ufug.2020.126647

Bartesaghi Koc C, Osmond P, Peters A (2017) Towards a comprehensive green infrastructure typology: a systematic review of approaches, methods and typologies. Urban Ecosyst 20:15-35. https://doi.org/10.1007/s11252-016-0578-5

Beck HE, Zimmermann NE, McVicar TR, Vergopolan N, Berg A, Wood EF (2018) Present and future köppen-geiger climate classification maps at $1-\mathrm{km}$ resolution. Sci Data 5:1-12. https://doi. org/10.1038/sdata.2018.214

Benedict M, McMahon E (2006) Green infrastructure: linking landscapes and communities. Island Press, Washington, DC

Boonsong K, Piyatiratitivorakul S, Patanaponpaiboon P (2003) Potential use of mangrove plantation as constructed wetland for municipal wastewater treatment. Water Sci Technol 257-266. https://doi.org/10.2166/wst.2003.0331

Bradshaw CJA, Sodhi NS, Peh KS-H, Brook BW (2007) Global evidence that deforestation amplifies flood risk and severity in the developing world. Glob Chang Biol 13:2379-2395. https://doi. org/10.1111/j.1365-2486.2007.01446.x

Brauman KA (2015) Hydrologic ecosystem services: linking ecohydrologic processes to human well-being in water research and watershed management. Wiley Interdiscip Rev Water 2:345-358. https://doi.org/10.1002/wat2.1081

Brears RC (2018) Blue-green infrastructure in managing urban water resources. In: Brears RC (ed), Blue and green cities: the role of blue-green infrastructure in managing urban water resources. Palgrave Macmillan, UK, London, p 43-61. https://doi.org/10. 1057/978-1-137-59258-3_2

Brix H, Koottatep T, Fryd O, Laugesen CH (2011) The flower and the butterfly constructed wetland system at Koh Phi Phi-System design and lessons learned during implementation and operation. Ecol Eng 37:729-735. https://doi.org/10.1016/j.ecoleng.2010.06.035

Brix H, Koottatep T, Laugesen CH (2007) Wastewater treatment in tsunami affected areas of Thailand by constructed wetlands. Water Sci Technol 69-74. https://doi.org/10.2166/wst.2007.528

Browder G, Ozment S, Rehberger Bescos I, Gartner T, Lange G-M (2019) Integrating green and gray: creating next generation infrastructure

Bui XT, Phan TH, Van, Nguyen TT, Vo TDH, Nguyen PD, Koottatep $T$ (2014) Performance of wetland roof with Melampodium paludosum treating septic tank effluent. Desalin Water Treat 52:1070-1076. https://doi.org/10.1080/19443994.2013.826323

Buisan ZA, Milano AE, Suson PD, Mostrales DS, Taclendo CS, Blasco JG (2019) The impact of sound land use management to reduce runoff. Glob J Environ Sci Manag 5:399-414. https://doi. org/10.22034/gjesm.2019.04.01

Chai CT, Putuhena FJ, Selaman OS (2017) A modelling study of the event-based retention performance of green roof under the hothumid tropical climate in Kuching. Water Sci Technol 76:2988-2999. https://doi.org/10.2166/wst.2017.472

Chaosakul T, Koottatep T, Irvine K (2013) Low impact development modeling to assess localized flood reduction in Thailand. J Water Manag Model R246-18. https://doi.org/10.14796/JWMM.R246-18

Chappell NA, Sherlock M, Bidin K, Macdonald R, Najman Y, Davies G (2007) Runoff processes in Southeast Asia: role of soil, regolith, and rock type. In: Forest environments in the Mekong River Basin. Springer, Japan, p 3-23. https://doi.org/10.1007/ 978-4-431-46503-4_1

Chua LHC, Tan SBK, Sim CH, Goyal MK (2012) Treatment of baseflow from an urban catchment by a floating wetland system. Ecol Eng 49:170-180. https://doi.org/10.1016/j.ecoleng.2012.08. 031

Colgan CS, Beck MW, Narayan S (2017) Financing natural infrastructure for coastal flood damage reduction 
Cornell University (2015) New York projected IDF curves [WWW document]. http://ny-idf-projections.nrcc.cornell.edu/. Accessed 27 Jul 2020

Danley-Thomson AA, Robbins DM, Gunsch CK (2016) Cocopeat for wastewater treatment in the developing world. II: field evaluation of constructed wetlands packed with cocopeat for wastewater treatment in Can Tho, Vietnam. J Environ Eng 142:04015070. https://doi.org/10.1061/(ASCE)EE.1943-7870.0000996

Depietri Y, McPhearson T (2017) Integrating the grey, green, and blue in cities: nature-based solutions for climate change adaptation and risk reduction. In: Kabisch N, Korn H, Stadler J, Bonn A (eds) Nature-based solutions to climate change adaptation in urban areas: linkages between science, policy and practice. Springer International Publishing, Cham, p 91-109. https://doi.org/10. 1007/978-3-319-56091-5_6

Diep L, Dodman D, Parikh P (2019) Green Infrastructure in informal settlements through a multiple-level perspective. Water Alter 12:554-570

Ditthabumrung S, Weesakul S (2019) Nature-based solution for flood management at Nong Sua District. Rangsit Canal, Thailand

Dreiseitl H, Asbjørn JL, Wanschura B (2015) Cost-benefit analysis of Bishan-Ang Mo Kio park. Singapore. Available at: https://ra mboll.com/-/media/files/rnewmarkets/herbert-dreiseitl_part-1_ final-report_22052015.pdf?la=en. Accessed 11 Apr 2021

Drosou N, Soetanto R, Hermawan F, Chmutina K, Bosher L, Hatmoko JUD (2019) Key factors influencing wider adoption of blue-green infrastructure in developing cities. Water 11:1234. https://doi.org/ 10.3390/w11061234

du Toit MJ, Cilliers SS, Dallimer M, Goddard M, Guenat S, Cornelius SF (2018) Urban green infrastructure and ecosystem services in sub-Saharan Africa. Landsc Urban Plan 180:249-261. https://doi. org/10.1016/j.landurbplan.2018.06.001

Eckart K, McPhee Z, Bolisetti T (2017) Performance and implementation of low impact development-a review. Sci Total Environ 607-608:413-432. https://doi.org/10.1016/j.scitotenv. 2017.06.254

Effendi H, Margaretha J, Krisanti M (2018) Reducing ammonia and chromium concentration in batik wastewater by vetiver (Chrysopogon zizanioides L.) grown in floating wetland. Appl Ecol Environ Res. https://doi.org/10.15666/aeer/1603_29472956

Engida T, Wu JM, Xu D, Wu ZB (2020) Review paper on horizontal subsurface flow constructed wetlands: Potential for their use in climate change mitigation and the treatment of wastewater. Appl Ecol Environ Res 18:1051-1089

Erkens G, Bucx T, Dam R, de Lange G, Lambert J (2015) Sinking coastal cities. Proceedings of the International Association of Hydrological Sciences. https://doi.org/10.5194/piahs-372-1892015

Estoque RC, Ooba M, Avitabile V, Hijioka Y, DasGupta R, Togawa T, Murayama Y (2019) The future of Southeast Asia's forests. Nat Commun 10:1829. https://doi.org/10.1038/s41467-01909646-4

Fletcher TD, Andrieu H, Hamel P (2013) Understanding, management and modelling of urban hydrology and its consequences for receiving waters: a state of the art. Adv Water Resour 51. https:// doi.org/10.1016/j.advwatres.2012.09.001

Fletcher TD, Shuster W, Hunt WF, Ashley R, Butler D, Arthur S, Trowsdale S, Barraud S, Semadeni-Davies A, BertrandKrajewski J-L, Mikkelsen PS, Rivard G, Uhl M, Dagenais D, Viklander M (2015) SUDS, LID, BMPs, WSUD and more-the evolution and application of terminology surrounding urban drainage. Urban Water J 12:525-542. https://doi.org/10.1080/ 1573062X.2014.916314

Frantzeskaki N (2019) Seven lessons for planning nature-based solutions in cities. Environ Sci Policy 93:101-111. https://doi.org/10. 1016/j.envsci.2018.12.033
Global Infrastructure Hub (2020) Global Infrastructure Outlook-a G20 Initiative [WWW document]. https://outlook.gihub. org/?utm_source $=$ GIHub + Homepage\&utm_medium $=$ Project + tile\&utm_campaign $=$ Outlook + GIHub + Tile. Accessed $27 \mathrm{Jul}$ 2020

Goh XP, Radhakrishnan M, Zevenbergen C, Pathirana A (2017) Effectiveness of runoff control legislation and active, beautiful, clean (ABC). Waters Des Features Singap Water 9:627. https:// doi.org/10.3390/w9080627

Gunawardena A, Zhang F, Fogarty J, Iftekhar MS (2017) Review of non-market values of water sensitive systems and practices: An update. Melbourne, Australia: Cooperative Research Centre for Water Sensitive Cities. Available at: https://watersensitivecities. org.au/content/review-of-non-market-values-of-water-sensitivesystems-and-practices-an-update/. Accessed 11 Apr 2021

Harriden K (2012) Potential impacts of slum urbanisation on channel bank storage in the Bang Pakong River, Thailand. Water Pract Technol 7. https://doi.org/10.2166/wpt.2012.071

Hatt B, Fletcher T, Deletic A (2008) Hydraulic and pollutant removal performance of fine media stormwater filtration systems. Env Sci Technol 42:2535-41

Salih GHA, Nadia S, Adnan B, Perumulselum P (2017) Removal of Pollutants using Bio-filtration with Three Different Plants as Biofilter. J Energy Environ 9:47-50

Hedglin D (2015) Tetris and the challenge of curbin Chinese sprawl [WWW document]. China Urban Development. https://www. chinaurbandevelopment.com/tetris-and-the-challenge-of-curbingchinese-sprawl/. Accessed 21 Dec 2020

Hermawan AA, Talei A, Salamatinia B, Chua LHC (2020) Seasonal performance of stormwater biofiltration system under tropical conditions. Ecol Eng 143:105676. https://doi.org/10.1016/j. ecoleng.2019.105676

Holmes D (2019) Chulalongkorn University Centenary Park - green infrastructure for the city of Bangkok [WWW document]. World Landscape Architecture. https://worldlandscapearchitect.com/ chulalongkorn-centenary-park-green-infrastructure-for-the-cityof-bangkok/\#.Xw-38pMzYWp. Accessed 16 Jul 2020

Hu P, Zhang Q, Shi P, Chen B, Fang J (2018) Flood-induced mortality across the globe: spatiotemporal pattern and influencing factors. Sci Total Environ 643:171-182. https://doi.org/10.1016/j. scitotenv.2018.06.197

Hughes AC (2017) Understanding the drivers of Southeast Asian biodiversity loss. Ecosphere 8:e01624. https://doi.org/10.1002/ ecs2.1624

Huu Loc H, Irvine KN, Suwanarit A, Vallikul P, Likitswat F, Sahavacharin A, Sovann C, Song Ha L (2020) Mainstreaming ecosystem services as public policy in South East Asia, from theory to practice BT-sustainability and law. In: Mauerhofer V, Rupo D, Tarquinio L (eds) General and specific aspects. Springer International Publishing, Cham, p 631-665. https://doi.org/10. 1007/978-3-030-42630-9_31

Irvine K, Sovann C, Suthipong S, Kok S, Chea E (2015) Application of PCSWMM to assess wastewater treatment and urban flooding scenarios in Phnom Penh, Cambodia: a tool to support eco-city planning. J Water Manag Model. https://doi.org/10.14796/jwmm. c389

Joshi P, Leitão JP, Maurer M, Bach PM (2021) Not all SuDS are created equal: Impact of different approaches on combined sewer overflows. Water Res 191:116780. https://doi.org/10.1016/j.wa tres.2020.116780

Kantawanichkul S, Somprasert S, Aekasin U, Shutes RBE (2003) Treatment of agricultural wastewater in two experimental combined constructed wetland systems in a tropical climate. Water Sci Technol 199-205. https://doi.org/10.2166/wst.2003.0319

Kato S, Hishiyama K, Agung Ketut Darmadi A, Ngurah Suprapta D (2017) Changing roles of traditional small urban green spaces 
(Telajakan) in Bali, In-donesia. Open J Ecol 7:1-11. https://doi. org/10.4236/oje.2017.71001

Keeler BL, Hamel P, McPhearson T, Hamann MH, Donahue ML, Meza Prado KA, Arkema KK, Bratman GN, Brauman KA, Finlay JC, Guerry AD, Hobbie SE, Johnson JA, MacDonald GK, McDonald RI, Neverisky N, Wood SA (2019) Social-ecological and technological factors moderate the value of urban nature. Nat Sustain. https://doi.org/10.1038/s41893-018-0202-1

Kefi M, Mishra BK, Kumar P, Masago Y, Fukushi K (2018) Assessment of tangible direct flood damage using a spatial analysis approach under the effects of climate change: case study in an urban watershed in Hanoi, Vietnam. Int J Geo-Information. https://doi.org/10.3390/ijgi7010029

Klepper O (1992) Model study of the negara river basin to assess the regulating role of its wetlands. Regul Rivers Res Manag 7:311-325. https://doi.org/10.1002/rrr.3450070402

Kok K, Sidek L, Abidin M, Basri H, Muda Z, Beddu S (2013) Evaluation of green roof as green technology for urban stormwater quantity and quality controls. IOP Conf Ser Earth Environ Sci. https://doi.org/10.1088/1755-1315/16/1/012045

Koottatep T, Polprasert C, Oanh NTK, Heinss U, Montangero A, Strauss M (2001) Septage dewatering in vertical-flow constructed wetlands located in the tropics. Water Sci Technol 181-188. https://doi.org/10.2166/wst.2001.0768

Lai SH, Mah DYS (2012) Field investigation of a dry detention pond with underground detention storage. Hydrol Sci J 57:1249-1255. https://doi.org/10.1080/02626667.2012.692016

Laituri M (2020) The hydrosocial cycle in rapidly urbanizing watersheds. Front Earth Sci 1-12. https://doi.org/10.1007/s11707-0200823-3

Lallemant D, Hamel P, Balbi M, Schmitt R, Lim TN, Win S (in press) Nature-Based Solutions for Flood Risk Reduction: A Probabilistic Modeling Framework. One Earth

Li Y, Lian J, Wu B, Zou H, Tan SK (2020) Phytoremediation of pharmaceutical-contaminated wastewater: Insights into rhizobacterial dynamics related to pollutant degradation mechanisms during plant life cycle. Chemosphere 253:126681. https://doi.org/ 10.1016/j.chemosphere.2020.126681

Liamlaem W, Benjawan L, Polprasert C (2019) Sustainable wastewater management technology for tourism in Thailand: case and experimental studies. Water Sci Technol 79:1977-1984. https:// doi.org/10.2166/wst.2019.200

Liang JB, Kayawake E, Sekine T, Suzuki S, Lim KK (2017) Developing zero-discharge pig-farming system: a feasibility study in Malaysia. Anim Prod Sci 57:1598. https://doi.org/10.1071/ AN15669

Liao K-H, Deng S, Tan PY (2017) Blue-green infrastructure: new frontier for sustainable urban stormwater management BTgreening cities: forms and functions. In: Tan PY, Jim CY (eds) Springer, Singapore, p 203-226. https://doi.org/10.1007/978981-10-4113-6_10

Lim HS, Lu XX (2016) Sustainable urban stormwater management in the tropics: an evaluation of Singapore's ABC Waters Program. J Hydrol. https://doi.org/10.1016/j.jhydrol.2016.04.063

Limthongsakul S, Nitivattananon V, Arifwidodo SD (2017) Localized flooding and autonomous adaptation in peri-urban Bangkok. Environ Urban 29:51-68. https://doi.org/10.1177/0956247816683854

Lin E, Shaad K, Girot C (2016) Developing river rehabilitation scenarios by integrating landscape and hydrodynamic modeling for the Ciliwung River in Jakarta, Indonesia. Sustain. Cities Soc 20:180-198. https://doi.org/10.1016/j.scs.2015.09.011

Liu L, Jensen MB (2018) Green infrastructure for sustainable urban water management: practices of five forerunner cities. Cities 74:126-133. https://doi.org/10.1016/j.cities.2017.11.013

Loc HH, Babel MS, Weesakul S, Irvine KN, Duyen PM (2015) Exploratory assessment of SUDS feasibility in Nhieu Loc-Thi
Nghe Basin, Ho Chi Minh City, Vietnam. Br J Environ Clim Chang 5. https://doi.org/10.9734/BJECC/2015/11534

Loh B (2012) A selection of plants for Bioretention System in the Tropics. Research Technical Note 04

Loh B, Hunt W (2013) Maintenance requirements for bioretention systems in the tropics

Lourdes KT, Gibbins CN, Hamel P, Sanusi R, Azhar B, Lechner AM (2021) A review of urban ecosystem services research in Southeast Asia. Land 10:40

Majidi V, Alves W, Sanchez B, Kluck (2019) Planning nature-based solutions for urban flood reduction and thermal comfort enhancement. Sustainability 11:6361. https://doi.org/10.3390/ su11226361

Maryati S, Humaira ANS (2017) Implementation of green infrastructure concept in Citarum Watershed. Proceedings of the AIP Conference Proceedings. American Institute of Physics Inc., p 020031. https://doi.org/10.1063/1.4976895

Masumoto T, Hai PT, Shimizu K (2008) Impact of paddy irrigation levels on floods and water use in the Mekong River basin. Hydrol Process 22:1321-1328. https://doi.org/10.1002/hyp.6941

McDonald RI, Mansur AV, Ascensão F, Colbert M, Crossman K, Elmqvist T, Gonzalez A, Güneralp B, Haase D, Hamann M, Hillel O, Huang K, Kahnt B, Maddox D, Pacheco A, Pereira HM, Seto KC, Simkin R, Walsh B, Werner AS, Ziter C (2020) Research gaps in knowledge of the impact of urban growth on biodiversity. Nat Sustain 3:16-24. https://doi.org/10.1038/ s41893-019-0436-6

Meerow S (2019) A green infrastructure spatial planning model for evaluating ecosystem service tradeoffs and synergies across three coastal megacities. Environ Res Lett. 14

Meutia AA (2001) Treatment of laboratory wastewater in a tropical constructed wetland comparing surface and subsurface flow. Water Sci Technol 499-506. https://doi.org/10.2166/wst.2001. 0872

Mitchell VG (2006) Applying integrated urban water management concepts: a review of australian experience. Environ Manag 37:589-605. https://doi.org/10.1007/s00267-004-0252-1

Møller KA, Fryd O, De Neergaard A, Magid J (2012) Economic, environmental and socio-cultural sustainability of three constructed wetlands in Thailand. Environ Urban 24:305-323. https://doi.org/10.1177/0956247811434259

Mononimbar WJ (2018) Slum upgrading based on flood mitigation for resilience of Manado City. IOP Conf Ser Earth Environ Sci 179. https://doi.org/10.1088/1755-1315/179/1/012008

Moosavi S, Browne GR, Bush J (2021) Perceptions of nature-based solutions for Urban Water challenges: insights from Australian researchers and practitioners. Urban For Urban Green 57:126937. https://doi.org/10.1016/j.ufug.2020.126937

Mulligan J, Bukachi V, Clause JC, Jewell R, Kirimi F, Odbert C (2020) Hybrid infrastructures, hybrid governance: New evidence from Nairobi (Kenya) on green-blue-grey infrastructure in informal settlements. Anthropocene 29:100227. https://doi.org/ 10.1016/j.ancene.2019.100227

Nagendra H, Bai X, Brondizio ES, Lwasa S (2018) The urban south and the predicament of global sustainability. Nat Sustain 1:341-349. https://doi.org/10.1038/s41893-018-0101-5

Nguyen MK, Nguyen TQH, Nguyen CM, Bui QL, Huyen D, Ozaki A (2020) Assessment of nutrients removal by constructed wetlands using Reed Grass (Phragmites australis L.) and Vetiver Grass (Vetiveria Zizanioides L.). J - Fac Agric Kyushu Univ 65:149-156

Ni WD, Zhang DQ, Gersberg RM, Hong J, Jinadasa KBSN, Ng WJ, Tan SK (2013) Statistical modeling of batch versus continuous feeding strategies for pollutant removal by tropical subsurface flow constructed wetlands. Wetlands 33:335-344. https://doi.org/ 10.1007/s13157-013-0389-x 
Ogata Y, Ishigaki T, Ebie Y, Sutthasil N, Chiemchaisri C, Yamada M (2015) Effect of feed pattern of landfill leachate on water reduction in constructed wetland in Southeast Asia. Water Pract Technol 10:669-673. https://doi.org/10.2166/wpt.2015.079

Ong GS, Kalyanaraman G, Wong KL, Wong THF (2012) Monitoring Singapore's first bioretention system: rain garden at Balam estate. Proceedings of the 7th International Conference on Water Sensitive Urban Design; Building the Water Sensitive Community, Final Program and Abstract B

Oral HV, Carvalho P, Gajewska M, Ursino N, Masi F, Hullebusch ED, van, Kazak JK, Exposito A, Cipolletta G, Andersen TR, Finger DC, Simperler L, Regelsberger M, Rous V, Radinja M, Buttiglieri G, Krzeminski P, Rizzo A, Dehghanian K, Nikolova M, Zimmermann M (2020) A review of nature-based solutions for urban water management in European circular cities: a critical assessment based on case studies and literature. Blue-Green Syst 2:112-136. https://doi.org/10.2166/bgs.2020.932

Ozment S, Ellison G, Jongman B (2019) Nature-Based Solutions for Disaster Risk Management: Booklet. World Bank Group. http:// documents1.worldbank.org/curated/en/253401551126252092/ pdf/134847-NBS-for-DRM-booklet.pdf

Payne E, Fowdar H, Marthanty DR, Pawitan H, Marsudiantoro D, McCarthy D (2019) Review of the application of green infrastructure for water management in Bogor. Monash University. https://doi.org/10.26180/5D47D51B809EA

Pongthornpruek S (2017) Swine farm wastewater treatment by constructed wetland planted with vetiver grass. Environ. Nat Resour J 15:13-20. https://doi.org/10.14456/ennrj.2017.8

Public Utilities Board Singapore (2018) Active, beautiful, clean waters design guidelines, 4th edn, Public Utilities Board, Singapore

Public Utilities Board Singapore (2013) Code of practice on surface water drainage, Public Utilities Board, Singapore

Qomariyah S, Xie A, Chen H, You S (2018) Linking climate change to water provision: greywater treatment by constructed wetlands. IOP Conf Ser Earth Environ Sci 129:12002. https://doi.org/10. 1088/1755-1315/129/1/012002

Rahmadyanti E, Wiyono A, Firmansyah GA (2020) Integrated system of biofilter and constructed wetland for sustainable batik industry. Int J GEOMATE. https://doi.org/10.21660/2020.70.61681

Rahmasary AN, Robert S, Chang I-S, Jing W, Park J, Bluemling B, Koop S, van Leeuwen K (2019) Overcoming the challenges of water, waste and climate change in Asian cities. Environ Manag 63:520-535. https://doi.org/10.1007/s00267-019-01137-y

Rambonilaza T, Neang M (2019) Exploring the potential of local market in remunerating water ecosystem services in Cambodia: an application for endogenous attribute non-attendance modelling. Water Resour Econ 25:14-26. https://doi.org/10.1016/j.wre. 2018.07.001

Ramirez-Lovering D, Marino Zamudio R, Arifin HS, Kaswanto RL, Simarmata, HA, Marthanty DR, Farrelly M, Fowdar H, Gunn A, Holden J, Panjaitan N, Payne E, Rogers B, Syaukat Y, Suharnoto Y, Suwarso R, Sondang I, Urich C, Wright A, Desrainy L, Brodnik C, Yuliantoro D (2019) Pulo Geulis Revitalisation 2045. Urban design and implementation roadmap. Australian-Indonesia Centre (AIC). https://australiaindonesiacentre.org/projects/casestudy-pulo-geulis-transition-roadmap-to-wsc

Redfern SK, Azzu N, Binamira JS (2012) Rice in Southeast Asia: facing risks and vulnerabilities to respond to climate change. In: Meybeck A, Lankoski J, Redfern S, Azzu N, Gitz V (eds), Building Resilience for Adaptation to Climate Change in the Agriculture Sector. FAO, Rome, p. 354

Rezaei AR, Ismail Z, Niksokhan MH, Dayarian MA, Ramli AH, Shirazi SM (2019) A quantity-quality model to assess the effects of source control stormwater management on hydrology and water quality at the catchment scale. Water 11:1415. https://doi. org/10.3390/w11071415
Richards DR, Passy P, Oh RRY (2017) Impacts of population density and wealth on the quantity and structure of urban green space in tropical Southeast Asia. Landsc Urban Plan 157:553-560. https:// doi.org/10.1016/j.landurbplan.2016.09.005

Ro C, Sovann C, Bun D, Yim C, Bun T, Yim S, Irvine KN (2020) The economic value of peri-urban wetland ecosystem services in Phnom Penh, Cambodia. IOP Conf Ser Earth Environ Sci 561:12013. https://doi.org/10.1088/1755-1315/561/1/012013

Rogers B, Ramirez D, Marthanty DR, Arifin HS, Farrelly M, Fowdar H, Gunn A, Holden J, Kaswanto RL, Marino Zamudio R, McCarthy D, Novalia W, Payne E, Suwarso R, Syaukat Y, Urich C, Wright A, Yuliantoro D (2019) Leapfrogging pathways for a water sensitive Bogor. Australia-Indonesia Centre (AIC). https://research.monash. edu/en/publications/leapfrogging-pathways-for-a-water-sensitivebogor

Runting RK, Bryan BA, Dee LE, Maseyk FJF, Mandle L, Hamel P, Wilson KA, Yetka K, Possingham HP, Rhodes JR (2017) Incorporating climate change into ecosystem service assessments and decisions: a review. Glob Chang Biol 23. https://doi.org/10. $1111 / \mathrm{gcb} .13457$

Sa'At SKM, Zaman NQ, Yusoff MS (2019) Effect of hydraulic retention time on palm oil mill effluent treatment in horizontal sub-surface flow constructed wetland. Proceedings of the AIP Conference Proceedings. American Institute of Physics Inc., p 020015. https://doi.org/10.1063/1.5117075

Sarabi S, Han Q, Romme AGL, de Vries B, Valkenburg R, den Ouden E (2020) Uptake and implementation of nature-based solutions: an analysis of barriers using interpretive structural modeling. J Environ Manag 270:110749. https://doi.org/10.1016/j.jenvman. 2020.110749

Sarabi SE, Han Q, Romme AGL, Vries B, de, Wendling L (2019) Key enablers of and barriers to the uptake and implementation of nature-based solutions in urban settings: a review. Resources 8:121. https://doi.org/10.3390/resources8030121

Satterthwaite D, Archer D, Colenbrander S, Dodman D, Hardoy J, Mitlin D, Patel S (2020) Building resilience to climate change in informal settlements. One Earth 2:143-156. https://doi.org/10. 1016/j.oneear.2020.02.002

Sawaittayothin V, Polprasert C (2007) Nitrogen mass balance and microbial analysis of constructed wetlands treating municipal landfill leachate. Bioresour Technol 98:565-570. https://doi.org/ 10.1016/j.biortech.2006.02.002

Setiawan I, Rohmat D (2018) Test the effectiveness of biopore in the framework of eco-campus development at Universitas Pendidikan Indonesia. IOP Conf Ser Earth Environ Sci 286:012015

Shuster WD, Bonta J, Thurston H, Warnemuende E, Smith DR (2005) Impacts of impervious surface on watershed hydrology: a review. Urban Water J 2:263-275. https://doi.org/10. 1080/15730620500386529

Shutes RBE (2001) Artificial wetlands and water quality improvement. Environ Int 26:441-447. https://doi.org/10.1016/S0160-4120(01) 00025-3

Sidek LM, Muha NE, Noor NAM, Basri H (2013) Constructed rain garden systems for stormwater quality control under tropical climates. IOP Conf. Ser.: Earth Environ Sci 16:012020

Sim CH, Yusoff MK, Shutes B, Ho SC, Mansor M (2008) Nutrient removal in a pilot and full scale constructed wetland, Putrajaya city, Malaysia. J Environ Manag 88:307-317. https://doi.org/10. 1016/j.jenvman.2007.03.011

Sinharoy SS, Pittluck R, Clasen T (2019) Review of drivers and barriers of water and sanitation policies for urban informal settlements in low-income and middle-income countries. Util Policy 60:100957. https://doi.org/10.1016/j.jup.2019.100957

Siripong H, Khao-uppatum W, Thanopanuwat S (2000) Flood management in the Chao Phraya Basin. In: Proceedings of the International Conference: The Chao Phraya Delta: historical 
development, dynamics and challenges of Thailand's rice bowl. Bangkok. https://horizon.documentation.ird.fr/exl-doc/pleins_ textes/divers15-09/010024645.pdf.

Song XP, Richards D, Edwards P, Tan PY (2017) Benefits of trees in tropical cities. Science 356:1241. https://doi.org/10.1126/science. aan6642

Sriwongsitanon N, Taesombat W (2011) Effects of land cover on runoff coefficient. J Hydrol 410:226-238. https://doi.org/10. 1016/j.jhydrol.2011.09.021

Sumarga E, Hein L, Hooijer A, Vernimmen R (2016) Hydrological and economic effects of oil palm cultivation in Indonesian peatlands. Ecol Soc. 21. https://doi.org/10.5751/ES-08490-210252

Tallis H, Mooney H, Andelman S, Balvanera P, Cramer W, Karp D, Polasky S, Reyers B, Ricketts T, Running S, Thonicke K, Tietjen B, Walz A (2012) A global system for monitoring ecosystem service change. Bioscience 62:977-986. https://doi.org/10.1525/ bio.2012.62.11.7

Tan-Soo J, Adnan N, Ahmad I, Pattanayak SK, Vincent JR (2016) Econometric evidence on forest ecosystem services: deforestation and flooding in Malaysia. Environ Resour Econ 25-44. https:// doi.org/10.1007/s10640-014-9834-4

Tran HD, Vi HMT, Dang HTT, Narbaitz RM (2019) Pollutant removal by Canna Generalis in tropical constructed wetlands for domestic wastewater treatment. Glob. J Environ Sci Manag 5:331-344. https://doi.org/10.22034/gjesm.2019.03.06

Trinh DH, Chui TFM (2013) Assessing the hydrologic restoration of an urbanized area via an integrated distributed hydrological model. Hydrol Earth Syst Sci 17:4789-4801. https://doi.org/10. 5194/hess-17-4789-2013

Trinh LT, Duong CC, Van Der Steen P, Lens PNL (2013) Exploring the potential for wastewater reuse in agriculture as a climate change adaptation measure for Can Tho City, Vietnam. Agric Water Manag 128:43-54. https://doi.org/10.1016/j.agwat.2013. 06.003

Tom M, Fletcher TD, McCarthy DT (2014) Heavy Metal Contamination of Vegetables Irrigated by Urban Stormwater: A Matter of Time? PLoS ONE 9, e112441. https://doi.org/10.1371/ journal.pone. 0112441

Ujang FA, Osman NA, Idris J, Halmi MIE, Hassan MA, Roslan AM (2018) Start-up treatment of palm oil mill effluent (POME) final discharge using Napier Grass in wetland system. IOP Conf Ser Mater Sci Eng 368. https://doi.org/10.1088/1757-899X/368/1/ 012008

UNEP-DHI Centre on Water and Environment (2020) IWRM data portal [WWW document]. http://iwrmdataportal.unepdhi.org/ global651data

US-EPA (2013) Case studies analyzing the economic benefits of low impact development and green infrastructure programs. US-EPA, Washington, DC

Venkataramanan V, Packman AI, Peters DR, Lopez D, Mccuskey DJ, Mcdonald RI, Miller WM, Young SL (2019) A systematic review of the human health and social well-being outcomes of green infrastructure for stormwater and flood management. J Environ Manag 246:868-880. https://doi.org/10.1016/j.jenvman.2019.05. 028

Vijayaraghavan K, Joshi UM, Balasubramanian R (2012) A field study to evaluate runoff quality from green roofs. Water Res 46:1337-1345. https://doi.org/10.1016/j.watres.2011.12.050

Vo HNP, Koottatep T, Chapagain SK, Panuvatvanich A, Polprasert C, Nguyen TMH, Chaiwong C, Nguyen NL (2019) Removal and monitoring acetaminophen-contaminated hospital wastewater by vertical flow constructed wetland and peroxidase enzymes. J Environ Manag 250:109526. https://doi.org/10.1016/j.jenvman. 2019.109526

Vollmer D, Grêt-Regamey A (2013) Rivers as municipal infrastructure: demand for environmental services in informal settlements along an Indonesian river. Glob Environ Chang 23:1542-1555. https://doi.org/10.1016/j.gloenvcha.2013.10.001

Walsh CJ, Fletcher TD, Bos DG, Imberger SJ (2015) Restoring a stream through retention of urban stormwater runoff: a catchment-scale experiment in a social-ecological system. Freshw Sci 34:1161-1168. https://doi.org/10.1086/682422

Wamsler C, Wickenberg B, Hanson H, Alkan Olsson J, Stålhammar S, Björn H, Falck H, Gerell D, Oskarsson T, Simonsson E, Torffvit F, Zelmerlow F (2020) Environmental and climate policy integration: targeted strategies for overcoming barriers to naturebased solutions and climate change adaptation. J Clean Prod 247:119154. https://doi.org/10.1016/j.jclepro.2019.119154

Wang J, Chua LHC, Shanahan P (2019) Hydrological modeling and field validation of a bioretention basin. J Environ Manag 240:149-159. https://doi.org/10.1016/j.jenvman.2019.03.090

Wang J, Chua LHC, Shanahan P (2017) Evaluation of pollutant removal efficiency of a bioretention basin and implications for stormwater management in tropical cities. Environ Sci Water Res Technol 3:78-91. https://doi.org/10.1039/c6ew00285d

Wang M, Zhang D, Adhityan A, Ng WJ, Dong J, Tan SK (2016) Assessing cost-effectiveness of bioretention on stormwater in response to climate change and urbanization for future scenarios. J Hydrol 543:423-432. https://doi.org/10.1016/j.jhydrol.2016.10. 019

Wang M, Zhang DQ, Adhityan A, Ng WJ, Dong JW, Tan SK (2018) Conventional and holistic urban stormwater management in coastal cities: a case study of the practice in Hong Kong and Singapore. Int J Water Resour Dev 34:192-212. https://doi.org/ 10.1080/07900627.2016.1258355

Wang M, Zhang DQ, Su J, Trzcinski AP, Dong JW, Tan SK (2017) Future scenarios modeling of urban stormwater management response to impacts of climate change and urbanization. CLEAN - Soil, Air, Water 45:1700111. https://doi.org/10.1002/clen. 201700111

Watkin R, Vojinovic W, Torres (2019) A framework for assessing benefits of implemented nature-based solutions. Sustainability 11:6788. https://doi.org/10.3390/su11236788

Wolf S, Pham M, Matthews N, Bubeck P (2020) Understanding the implementation gap: policy-makers' perceptions of ecosystembased adaptation in Central Vietnam. Clim Dev 1-14. https://doi. org/10.1080/17565529.2020.1724068

World Bank (2017) Implementing nature-based flood protection: principles and implementation guidance

World Bank (2016) The role of green infrastructure solutions in urban flood risk management

World Health Organisation and UNICEF (2017) Joint Monitoring Programme for water supply, sanitation and hygiene [WWW document]. https://washdata.org/. Accessed 9 Jul 2020

World Wildlife Fund and US-AID (2016) Natural and nature-based flood management: a green guide. https://www.worldwildlife.org/ publications/natural-and-nature-based-flood-management-agreen-guide

Yap KS (2018) Peri-urban transformations in Southeast Asia. In: Padawangi R (ed) Routledge handbook of urbanization in Southeast Asia, 1st edn. Routledge, London. p 12

Yau W, Radhakrishnan M, Liong S-Y, Zevenbergen C, Pathirana A (2017) Effectiveness of $A B C$ waters design features for runoff quantity control in urban Singapore. Water 9:577. https://doi.org/ 10.3390/w9080577

Yi NJ, Samira F, Stefano G (2020) Do design storms yield robust drainage systems? How rainfall duration, intensity, and profile can affect drainage performance. J Water Resour Plan Manag 146:4020003. https://doi.org/10.1061/(ASCE)WR.1943-5452.0001167

Yirong C, Puetpaiboon U (2004) Performance of constructed wetland treating wastewater from seafood industry. Water Sci Technol 49:289-294. https://doi.org/10.2166/wst.2004.0766 
Zhang D, Ni W, Gersberg RM, Ng WJ, Tan SK (2015) Performance characterization of pharmaceutical removal by horizontal subsurface flow constructed wetlands using multivariate analysis. CLEAN - Soil, Air, Water 43:1181-1189. https://doi.org/10.1002/clen.201400294

Zhang DQ, Gersberg RM, Hua T, Zhu J, Tuan NA, Tan SK (2012) Pharmaceutical removal in tropical subsurface flow constructed wetlands at varying hydraulic loading rates. Chemosphere 87:273-277. https://doi.org/10.1016/j.chemosphere.2011.12.067
Zhang K, Deletic A, Dotto CBS, Allen R, Bach PM (2020) Modelling a 'business case' for blue-green infrastructure: lessons from the Water Sensitive Cities Toolkit. Blue-Green Syst 2:383-403. https://doi.org/10.2166/bgs.2020.018

Zhang K, Manuelpillai D, Raut B, Deletic A, Bach PM (2019) Evaluating the reliability of stormwater treatment systems under various future climate conditions. J Hydrol 568:57-66. https:// doi.org/10.1016/j.jhydrol.2018.10.056 